\title{
Global perspectives and impacts on Canada's environment
}

\author{
by E.S. (Bert) Reid, R.P.F., P. Eng.
}

The greatest threat to the future world environment is that of the uncontrolled population increase and the resulting severe land and air degradation. Global population in 1990 was estimated at 5.3 billion, and is expected to double to 10 billion early in the next century. The UN Population Fund Report of 1990 stated "we cannot solve the environmental crisis without solving the population crisis". An equal danger to a stable and acceptable global environment are the excessive demands and wasteful use of resources by the Western world's society. Twenty-five percent of the population uses $80 \%$ of the worlds resources. Some authorities state that "the impact of each Canadian on the environment is the equivalent of that of 40 to 50 third world residents." Canada will be increasingly impacted by these global environmental issues whether we like it or not. The greatest threat will be that we do not recognize this fact and that we do not prepare ourselves for sustained resource use. However, there are great opportunities for Canadian resource planners and users to play a leading role in adopting a sustained, long term forestry vocation in respect of the use of all its resources; and demonstrate to the global community how essential this is for a stable economy, a moderate lifestyle, and a protected environment. We have the technological capability and the proven expertise to achieve this, if we care to use it appropriately. The major task is "selling" this integrated sustained use or sharing concept to Canadian society because of the required sacrifices in lifestyles, economic costs, and certain environmental degradation. In the short term, progress can be made with public input to commissions, hearings and the like; but in the long term, a rational understanding of sustained forest use and conservation can only be achieved through education in all forms at all ages. An appreciation of global forest and related environmental issues, and their impacts on Canada, can facilitate positive Canadian action to practical sustained use of all forest and natural resources, in both a national and global context.
La plus grande menace pour l'environnement mondial dans le futur réside dans la croissance incontrôlée de la population et dans la dégradation importante des sols et de l'air qui en découle. La population mondiale en 1990 était estimée à 5.3 milliards, et devrait doubler pour atteindre 10 milliards au début du prochain siècle. Le rapport des Nations-Unies sur la population mondiale en 1990 soulignait que "nous ne pouvons résoudre la crise environnementale sans résoudre la crise de surpopulation". Les demandes excessives et l'utilisation selon des habitudes de gaspillage des ressources par la société du monde occidental constituent également un danger pour un environnement mondial stable et acceptable. Vingt-cinq pourcent de la population utilise $80 \%$ des ressources mondiales. Certains spécialistes déclarent que "l'impact de chaque Canadien sur l'environnement équivaut à celui de 40 à 50 résidents du tiers monde". Le Canada subira de plus en plus l'impact de ces questions environnementales mondiales qu'on le veuille ou non. Ne pas reconnaitre les faits et ne pas se préparer à une utilisation soutenue des ressources constituent la plus importante menace qui puisse nous atteindre. Cependant, les planificateurs et les utilisateurs canadiens de ressources auront de grandes chances de jouer un rôle déterminant en adoptant une vocation forestière soutenue et à long terme pour ce qui est de l'utilisation de toutes les ressources, ainsi qu'en démontrant au monde entier comment cela est essentiel dans le cas d'une économie stable, d'un monde de vie modéré, et d'un environnement protégé. Nous avons la capacité technologique ainsi qu'une expertise établie pour réaliser cela, advenant que nous ayons le souci des utiliser adéquatement. Le principal défi est de "vendre"'cette utilisation intégrée et soutenue ou de partager ce concept avec la société canadienne parce qu'il comporte des sacrifices au sein de notre style de vie, des coûts économiques, et une certaine dégradation environnementale. A court terme, des progrès peuvent être réalisés grâce à l'apport du public lors des commissions, des audiences et autres, mais à long terme, une compréhension rationnelle de l'utilisation soutenue et de la conservation des forêts ne pourra être atteinte que par l'éducation sous toutes ses formes et à tous les âges. L'évaluation des questions forestières mondiales et des questions environnementales qui s'y rapportent ainsi que de leurs impacts au Canada, peut faciliter une action positive de la part des Canadiens en matière d'utilisation soutenue et pratique de toutes les ressources forestières et naturelles, à la fois dans un contexte national et mondial.

\section{Introduction}

Canadians must recognize what is and will be taking place in the global rural and urban environments, and take this into account when planning for long term sustained resource use here at home. They must also consider future acceptable resource development options and lifestyles that can be sustained at home as well as abroad. This paper attempts to illustrate some of the global resource use and environmental degradation practices taking place, resulting impacts, and some considerations for remedial action. Canadians can no longer be insular in their thinking in this respect.

\footnotetext{
Paper presented at: Canadian Institute of Forestry Annual Meeting, Vancouver, BC, September 21-24, 1992.

Consultant in International Forestry and Environment Conservation, Qualicum Beach, BC.
}

\section{World Population}

\section{Rural and Urban Populations}

The greatest danger facing the survival of the world's environment is that of the uncontrolled world population increase. In 1990 , world population was estimated at 5.3 billion, increasing another billion (another equivalent Peoples Republic of China) by the end of this decade. It is predicted to rise to 10 billion relatively early in the next century. The United Nations further states that the world population won't stop growing until early in the 22nd century and by then it could be as high as 14 billion. This population increase, which will occur for the most part in developing countries, will dramatically affect both their rural and urban societies.

Presently, largely rural populations in the Developing World have an ever increasing demand for less and less available land and resources, while land under cultivation is becoming increasingly non productive. To a large extent 
because of this lack of land and resources and lost opportunities, more than two thirds of the population growth will take place in the urban environment. By the year 2000 it is expected that half the world's population, or some three billion, will live in cities. By this same time, it is predicted that 22 of the world's cities -17 of which will be in the developing world - will have populations in excess of 10 million people. Mexico City's population is expected to be over 26 million or about equivalent to all of Canada at present (and one can hardly breath there now); Sao Paulo, Brazil, increases 400,000 per year and will be at 24 million, and Yokohama, Japan, with over 17 million. And reflect on such global averages, where one huge metropolis of 10 million inhabitants every day consumes 6.2 billion litres of water (approximately 1.4 billion gallons), 20 thousand tonnes of food, 95 thousand tonnes of fuel, and generates 5 million tonnes of waste water, 20 thousand tonnes of solid waste, and 9.4 tonnes of air pollution. Just one city!

\section{Population Densities, Pressures, and Perspectives}

One has to visualize the population pressures in the developing world to appreciate their significance to environmental degradation. In 1987, working throughout the Philippines, one could see the adverse effects of the 55 million inhabitants on the rural and urban environment. In 1991, the country's population had grown by close to 7 million to approximately 62 million, and was expected to reach close to 80 million by the end of this decade. And this island archipelago has a total land area of $75 \%$ of that of Newfoundland. Picture for a moment if you will, 80 million people living in Newfoundland! Sri Lanka is rapidly approaching 20 to 22 million on a land mass equivalent to that of New Brunswick. Java in Indonesia, one of the most densely populated areas in the world, contains 108 million people or 717 persons $/ \mathrm{km}^{2}$. Canada supports 2.6 persons per square kilometer, or approximately 5 if one were only to count the southern half.

The global population question has many parameters but to put these concerns in some perspective, consider this: some reports state that seven babies are born every second in Asia, which would equate to over 600 thousand per day if they all lived. In actual fact, the world's population increases by about 250 thousand or one-quarter million per day. In Kenya, an average of 8.1 children are born to every woman. CIDA states that the projected population growth in the developing world will most likely be the dominant factor affecting virtually every aspect of human and social development, natural resource and environmental management, and economic progress over the next half century. And the 1990 UN Population Fund report states that "we cannot solve the environmental crisis without solving the population crisis."

\section{The Developing World's Practices and Impacts on Resources and Environment \\ Expanding Rural Population}

Rapidly expanding rural populations of agrarian based societies of the developing countries are demanding more and more of less and less available land for subsistence farming and living. They do not yet have any other alternatives to put food in their stomachs today and tomorrow. This fact is starkly evident as one travels about many parts of the Philippines, Thailand, Sri Lanka, along the Andean mountain chain, or the desert prone areas of Africa. Logging in many cases initiates deforestation and land degradation of these areas but has not been the main factor. It is the land settlement, mostly by so called "squatters" illegally pushing their way up the valleys and mountain sides or across the plateaus, settling on these lands and carrying out subsistence land use practices of burning, tillage and cropping that cause the major environmental degradation.

\section{Tropical Rain Forest and Deforestation}

The situation in most of the lowland tropical rain forests is much the same as in the upland zones, and this is the pressure for land and subsistence living by rural populations. Sensational statements, which the media are prone to headline, like "the world's forests are being shaved (or ravaged or raped) at the rate of 10-12 million hectares per year because of logging" are just not true. Yes, deforestation is probably taking place at that or a greater rate, but there are many other forces at work in the cutting down of the tropical forests.

We hear much about logging and the resulting deforestation and land degradation in the Amazon, but logging is one small part of a much greater problem regarding deforestation. Generally speaking on a global scale, deforestation is caused by the following activities, and from my observation, probably somewhat in this order: legal land colonization of vast areas unsuitable for agriculture; excessive encroachment by illegal slash and burn shifting cultivators; cutting for fuel wood utilization by developing country populations (still the greatest use of wood in the world); extensive land clearing for cattle ranching; large commercial agricultural estate-type forest conversions and resettlements to generate cash export crops; logging; extensive clearing and flooding for large scale hydro power and irrigation schemes; and extensive cutting for open pit gold and precious gem mining. Most of these areas are not reforested and therefore have no long term forestry vocation. To equate BC as a "Brazil of the North" is ludicrous in the extreme and mischievious sensationalism.

Many Western "week-end" single interest experts in addition to apparently well informed people, advocate immediate cessation of all tropical forest logging or forest removal. This might be ideal philosophy, but we don't live in an ideal world. As is so often the case in similar instances, the human factor in the tropical deforestation equation is mostly overlooked. We must recognize and account for the strong interrelationships between political, religious, cultural, social, and economic factors at work in this situation. It is useless to advocate stopping the felling and burning of tropical forests unless we have viable options to offer and put in place at once so that there is food to put in the peasant's belly for the next day.

Therefore, the growing billions of underpriviledged people of the developing world's upland valleys, hills and mountain areas, combined with the inhabitants of the tropical lowlands, will increasingly deforest and degrade the rural environment at an alarming rate. They will not do this because they particularly want to, but because there is no other realistic alternative offered.

\section{Resource Use and Trends}

Despite the abject poverty of one billion or more people (less than equivalent of $\$ 370 /$ year) and another two billion or so severely disadvantaged in the developing countries, overall the per capita consumption of goods and services is 
rising quite rapidly. It rose $70 \%$ over a 20 year period $1965-85$, together with an increase in life expectancy. This trend can be expected to continue which causes a "triple whammy" to these countries involved. The per capita incremental resource use - and an increase in the degradation factor - over the next few decades, when combined with population and life expectancy increase, will have a tremendous impact on all environmental issues and on society as a whole.

\section{Impacts on Canada}

One might ask "what have these population growth and statistics to do with Canada's environment issues?" The population and attendant demand for land, natural resources, and for a better standard of living will have a profound effect on our western society. The whole world can expect to experience a greatly increased resource depletion, land degradation, and toxic emissions into the atmosphere. Canada cannot escape from these effects, and can expect to be severely affected by the economic, population migration, and social issues.

One present relatively small economic example is that Canadian Banks have provided \$27 billion in loans to developing countries with debt servicing problems. In the opinion of some experts we will most likely have to cancel these loans. Who pays this $\$ 27,000$ per capita Canadian debt? The banks are only the messengers. As to population migration, can we build a "great wall of Canada" around our borders to sustain $2.5-5$ people per $\mathrm{km}^{2}$, while some other countries are fast approaching the thousand persons per $\mathrm{km}^{2}$ mark? I think not. I am not condoning what is happening in the developing world; I am merely stating the facts, the realities of life, and how they will impact on our future, whether or not we agree with it or like it.

\section{The Developed World's Consumptive Practices and Effects}

\section{Consumption}

The second greatest danger to a stable and acceptable global environment, and actually parallel and probably equally as serious as the population crisis, is the excessive demands on, and much wasteful use of resources by the developed world. Authoritative reports state that $25 \%$ of the world's population (i.e., the developed world) consumes $80 \%$ of the world's non-renewable resources such as metals and fossil fuels, $75 \%$ overall of world's resource capital, and $70 \%$ of the world's commercial energy.

Our lifestyles are extravagant in the extreme when compared to the less fortunate four billion human inhabitants. It is not out of the norm for affluent North Americans to have and sustain huge homes of 4,000 to 8,000 square feet with all the modern gadgetry, large swimming pools, spas, two to three cars in each driveway, beach cottages, ski condos, power and sail boats, campers, motor homes, wear designer clothes to accompany a "jet-set" entertainment lifestyle. This lifestyle places a serious strain on resource use and we have to question ourselves whether we can, or should, even try to maintain a "street of dreams" philosophy, which is not far short of Robin Leach's "lifestyles of the rich and famous".

A University of BC environmentalist planner recently stated that the impact of each Canadian on the environment is equivalent to that of 40-50 inhabitants of the developing world. My observations lead me to believe that is a conservative statement. He further went on to say that Canadians are among the world's greatest contributors to global environmental deterioration. In our affluent society there never seems to be enough: consumption is the rule, and demand is not dictated by available sustained supply.

The former Norwegian Minister of the Environment, Rakel Surlien, stated that "the industrialized world's demands for raw materials, higher productivity, and for material goods have imposed serious environmental impacts and high economic costs, not only in our own countries, but also in the developing world."' I would go on to say if this is the case for the past few decades, think about what it is going to be like for the years ahead.

\section{Waste}

Hand-in-hand with the excessive demand on resources by the developed world is our "throw-away-mentality". Planned obsolescence is said to guide production. Garbage anthropologists say that the average American household is a "round-the-clock" trash factory, generating in one week 6.73 bags of garbage or, in one year, 350 bags or almost one bag per day per family. Each year, Japanese consumers use 30 million disposable single-roll cameras, and Americans throw away 16 billion disposable diapers, 220 million tires, and enough aluminum to rebuild the entire US commercial air line fleet every three months.

Not including sludge and construction wastes, Americans collectively toss out 160 million tons each year - enough to spread 30 stories high over 1,000 football fields, or enough to fill a bumper to bumper convoy of garbage trucks halfway to the moon. Even comic strips now allude to this waste. "It is one of those great mysteries of life in America," mutters the cartoon character Shoe as he puts his groceries away. "In just one day, how do two bags of ordinary groceries turn into three bags of garbage?" Except that it is not really comical anymore.

\section{Vehicles}

There are presently estimated to be over 400 million vehicles in the world with the number expected to increase two and a half times to approximately one billion in just over 25 years. Collectively, this present impact on the global roads and the atmosphere is staggering. They burn almost $50 \%$ of the fossil fuels and are estimated to generate $40 \%$ of the U.S. nation's smog (with $15 \%$ coming from industry). Canada is said to have 13 million passenger vehicles on Canadian roads or one for every two persons - more than double that of 20 years ago - and add to that the number of commercial vehicles. Experts warn that automobile pollution will double along with the car population, unless stringent controls are introduced and enforced.

Back to Mexico City and the automobile as an illustration of future urban environmental nightmares. This is presently the world 's largest metropolis and reported to be one of the most polluted places on earth. It now has over three million vehicles. Authorities recently had to try and close down city traffic for one day in this city as it is becoming a death trap for destitute and physically defenceless citizens. Reflect for a moment what it will be like in Mexico City - and many other large urban centres - when that city's population exceeds 26 million with a corresponding increase in vehicles.

But we in North America do not need to be smug or point fingers. Every year each American, with Canadians close 
beside, generates five times as much heat trapping carbon dioxide as the average Brazilian, which translates into eight times as much greenhouse gases pumped into the atmosphere when considering total population. And each Canadian consumes seven times as much plastic - a non-renewable resource - as the average Brazilian. It is rather hypocritical of us to deride the Amazon peasant for cutting and burning the rain forest to eke out a living, while we are worse offenders in many respects to environment degradation.

\section{Resource Sustainability \\ Global}

It has been stated by numerous experts that the adoption of practices to sustain our resources and conserve our environment is not a game but a deadly serious business to billions of people. I agree, but effectively doing something positive about it in a meaningful way on a global scale is another thing - as was witnessed at the recent Brazil Earth Summit. There are, of course, many complex factors affecting sustained use of resources, environment conservation, and environment degradation - not the least of which is the "mind-set" and attitudes of millions of individuals to the concept of practical shared use of resources, and lack of a realistic, objective understanding of the impacts of resource use and overuse affecting us as individuals.

Industries, governments, and nations have to follow the will of the people for "sustainability" to be an effective force, and this starts with the person willingly and automatically picking up his garbage before he leaves the beach or park. It does not mean solely "green, save the world" rhetoric at a high profile public rally. My 40 years in this business, over 30 of which has been travelling the globe and observing what has, and is taking place, i.e, the changes, to a large extent adverse, doesn't make me very optimistic for substantial improvements regardless of the rhetoric one hears. An example of this was the statement by some US environmental authorities: "Though it's comforting to blame distant corporations, the man/woman in the street is just as dangerous. Industry produces $15 \%$ of the nation's smog, but cars (i.e., individuals) produce $40 \%$ ". And this $40 \%$ figure appears to be growing substantially.

In my own opinion, I believe little effective change for the better on a global scale will be realized unless we first come to grips with the twin monsters of the alarming population crisis in the developing world, and the excessive and wasteful resource use practices of the affluent developed world. Technological advances and an enlightened political attitude to distribution of food surpluses can alleviate some of the strain on resources and environment, but sheer numbers alone, taken together with ever increasing demands for goods and services by six billion people will, in my opinion, nullify most, if not all gains. In simplistic terms, as a starter, family planning concepts must be adopted much more effectively in the developing world and more moderate lifestyles accepted in the developed world. This strategic step is a monumental task in itself and this is why I am not overly optimistic.

\section{Canada's Options}

This predicted situation does not mean we Canadians should not try and be leaders in practising and demonstrating to others sustained use and environment conservation. In fact, it should be a stimulant for positive action on our part. I have seen enough of the nations of the world and its people to firmly believe we can contribute significantly. Canada has abundant land, sea, and atmospheric resources, capable people and a relatively good world reputation to enable it to formulate, adopt, and demonstrate reasonable and acceptable sustainable lifestyle practices. But attitudes to use and conservation issues have to change considerably.

With respect to the forest and natural resource sector of Canada, in my opinion we must emphasize conservation and wise use, and rationalize preservation in this context. Preservation is extremely important but I can see it being limited to special, significant areas of biological and/or ecological diversity. It is overly idealistic to think that we can return to the "good old days of the depression" 60 years ago when I grew up in northern B.C. where all was more or less a pristine wilderness.

It would be nice in a benevolent sense to lock up all or vast areas of our forests and natural resources and throw the key away, but I can assure you that won't be possible for the long term. The 6,10 , or 14 billion inhabitants of the earth will have other plans, rightly or wrongly. Therefore, the sooner we adjust to and adopt so called integrated multiple sustained use sharing concepts and practices, and recognize that ecosystems everywhere cannot be reserved intact, and that limited environmental degradation will take place, the more likely we are to be successful in our resource use planning and in coping with environmental problems.

\section{Conclusions}

Canadians will be increasingly affected by global environmental issues. The greatest threat or danger will be that we do not recognize this fact, and the need to prepare ourselves for sustained shared resource use. At the same time, there are great prospects and opportunities for Canadian resource planners and all users to play a significant leading role in adopting a sustained forestry vocation in respect of all forest and land resources; and to demonstrate to the global community how essential this is for a stable economy, for social security, a protected environment, and a moderate lifestyle. We have the technological capability and the proven expertise in world wide forestry as well as at home - and in many other resource disciplines - to achieve this goal, if we care to use it appropriately.

The major task ahead of us is "selling" this "integrated sustained use or sustained sharing concept" to Canadian society because of the required sacrifices to ingrained lifestyles, economic and social cost, and certain limited environmental degradation. In the short term, progress can be made through public participation and input to commissions, hearings and the like but in the long term, a rational understanding of sustained forest use and conservation can only be achieved through education. This must take place in primary and secondary schools, institutions of advanced education, through outdoor clubs and recreation groups, informed and objective public information campaigns, and from a well informed and objective media. That is, education in all forms at all ages, but concentrating on the youth of our nation.

As forestry in its many forms is a renewable resource, I truly believe it can be, as we wish, a cornerstone of 
Canadian society. A real appreciation of global rural and urban environmental issues, and their growing serious impacts on all Canadians and their way of life can facilitate positive Canadian action to practical sustained and shared use of all forest and natural resources, in a provincial, national, and global context.

\section{Acknowledgements}

The author wishes to acknowledge, with thanks, various agencies and documented sources for supplementing and confirming his own observations and findings on global environmental perspectives. These sources were: Statistics Canada reports, Canadian International Development Agency publications and reports on World Development, Environment, and Forestry, The World Bank reports and Atlas, United Nations publications including The World Commission on Environment and Development, and numerous Forestry Canada reports, professional journals, and newspaper articles written over the past decade on the subjects of global forestry, resources, and the rural and urban environments.

\section{Membership Dues 1992-1993}

\section{Active Membership}

1 st and 2 nd year after graduation

(grad 1992, grad 1991)*(\$2.49 G.S.T. inc.)

Other new members for first year *(\$2.49 G.S.T. inc.)

Married or equivalent

second member only *(\$2.49 G.S.T. inc.)

All other active members $*(\$ 2.49$ G.S.T. inc.)

\section{Other Memberships}

Retired members (to qualify for retired status, member must have 15 years membership in the Institute) $*(\$ 2.49$ G.S.T. inc.)

Student Members * $(\$ 1.31$ G.S.T. inc. $)$

Sustaining Individuals (CIF/IFC Members)

Sustaining Corporate $*(\$ 4.98$ G.S.T. inc. $)$

Upon written application, spousal members of Active Members may have the dues of one reduced by an amount determined annually. Spousal members are members of the same Section who are living together as spouses and using the same mailing address.

The Institute year runs from July 1 to June 30. Applications dated after January 1, 1992 will be charged half dues for that Institute year. Applications dated after April 1st will be charged NO DUES for that Institute year.

Section dues are in addition and range from $\$ \mathbf{5 . 0 0}$ to $\$ \mathbf{3 0 . 0 0}$ per Institute year.

*Note: The portion of membership which covers the cost of the Forestry Chronicle is subject to G.S.T. For tax purposes, this cost is calculated on $\$ 38.00$ which is $\$ 2.49$ G.S.T. (except Student rate of $\$ 20.00 @ \$ 1.31$ G.S.T.) 